\title{
The early history of Stanford Immunology
}

\author{
Patricia P. Jones • Leonore A. Herzenberg
}

Published online: 8 May 2014

(C) Springer Science+Business Media New York 2014

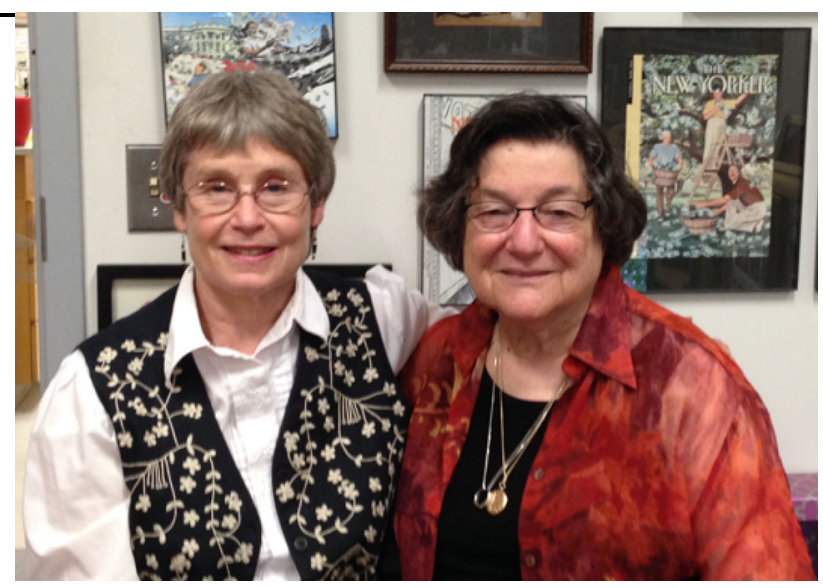

Patricia P. Jones and Leonore A. Herzenberg

\begin{abstract}
From its 1960 beginnings in a pair of windowless Genetics Department laboratories under the Stanford Medical School Dean's Office to its current broad-based program, which joins faculty members from departments across the Medical School, the Stanford Immunology Program has played a central role in shaping both basic and clinical immunology thinking. In this article, we tell the story of the beginnings of this odyssey in a reminiscence-based format that brings the flavor of the time in the words of people who lived and built the history.
\end{abstract}

\section{The foundations of Stanford Immunology}

Josh Lederberg, Len and Lee Herzenberg, and the early Stanford Immunology community

Shortly before 1960, the basic science and medical halves of the Stanford Medical School were united on the main Stanford campus in Palo Alto. Joshua Lederberg had only just received the Nobel Prize for discovering "sex in bacteria" in 1958, and Arthur Kornberg was yet to be so honored for "synthesizing DNA in a test tube." It would be another 2 or 3 years until the DNA $\rightarrow$ RNA $\rightarrow$ protein mantra would be broadly established as the central dogma of genetics, and the E. coli lacZ operon would be broadly recognized as modeling the genetic control of enzyme (and other) protein synthesis. However, these ideas were already appreciated at the newly reorganized medical school, their importance having been anticipated by faculty leaders Henry Kaplan, Avram Goldstein and others planning the Medical School shift from "the

P. P. Jones $(\bowtie)$

Department of Biology, Gilbert Biological Sciences Bldg., 371 Serra Mall, Stanford University, Stanford, CA 94305-5020, USA e-mail: patjones@stanford.edu

L. A. Herzenberg

Department of Genetics, Stanford University School of

Medicine, Beckman Center, 279 Campus Drive, Stanford, CA 94305-5318, USA
City" to "the Farm." In a prophetic move that laid the groundwork for the school as we know it, they appointed Kornberg to head Biochemistry and Lederberg to head Genetics, thus establishing an interactive basic science axis that would make enormous strides in biochemical and molecular genetics and would lay the groundwork for molecular medicine as we know it today.

Immunology, which was part of the Medical School basic science "half", was already established on the Farm when the move occurred. Like leading immunology groups elsewhere, its work was largely focused on antibody structure, antibodyantigen reactions, complement binding and, with respect to disease, establishing methods for inducing and measuring immune responses to pathogens. Sidney Raffel, George Feigen and others in the school were doing forefront work in these areas. However, they were also excited about the new vision driving the school and had joined Kaplan and Goldstein in developing a school-wide recruiting approach where research interests and collaborations crossed departmental lines. Ultimately, this effort would turn out to bring innovative genetic thinking to bear on basic and clinical studies of the immune system and would play a major role in shaping immunology as we know it today.

Sidney Raffel, who studied immune responses to pathogens, was a key early Stanford immunologist in the Department of Medical Microbiology (now Microbiology and Immunology) from 1936 to 1976; he served as department head for the last 23 of those years. "He made immunology a real discipline within the medical school," 
according to Irving Weissman, current faculty member who was a Stanford medical student mentored by Raffel. Sid Raffel played a major role in selecting and recruiting Halsted Holman, who had worked with Henry Kunkel at the Rockefeller Institute, as the chair of the Department of Medicine in 1959. Holman's research focus on genetic influences in autoimmune disease, notably systemic lupus erythematosus, brought a new approach to lupus therapy [1]. In addition, his approach instituted a model for the cross-department research collaboration that became a hallmark of the new immunology and a magnet for research-minded medical faculty, ultimately resulting in the appointments of Hugh McDevitt, Sam Strober, Ron Levy and Garry Fathman (to name only a few of current faculty "elders") and the deep involvement of the clinical faculty in basic science research.

The Lederberg and Kornberg appointments clearly played a crucial role in wedding immunology to the new genetics. Kornberg effectively brought his whole department with him from St. Louis. Although this included Jacques Monod colleague Melvin Cohn, whose very broad interests already included a burgeoning focus on how antibody specificity was acquired in the mammalian immune system, Kornberg's vision for the new department largely retained its focus on the biochemistry and molecular biology of $E$. coli and other model nonmammalian organisms.

Lederberg took quite a different approach. After arriving as head of the newly minted Department of Genetics in 1959, he appointed only his long-term collaborator (and wife) Esther Lederberg and a few $\mathrm{PhD}$ students to continue his previous work in bacterial genetics. He then reserved the rest of his future appointments for faculty who wanted to explore new frontiers related to his extremely broad interests, which, for the moment, were focused on mammalian cell genetics, including the genetic mechanisms underlying the generation of antibody diversity.

Before Lederberg actually took up residence at Stanford, he went to Australia to meet with Sir MacFarlane Burnet and spend some time learning about how "Sir Mac" saw the cell-based mechanisms enabling antibody diversity. There were two key outcomes from this visit: what is often referred to as the Lederberg-Burnett clonal selection theory of the origins of antibody diversity; and a seminal paper [2] that Lederberg published with Gus Nossal (now Sir Gustav J. V. Nossal), who ultimately became the long-term head of the Walter and Eliza Hall Institute in Melbourne but was then a young fellow in Sir Mac's laboratory. This paper [2], coming on the heels of work done independently by David Talmadge, Nils Jerne and Sir Mac [3], established that individual antibody-producing cells taken from rats immunized with a mixture of two distinct bacterial coat antigens produce antibodies specific for one or the other of the antigens, never both. This article serves essentially as a point source for all modern immunology concerned with the origins of specificity in immune responses.

Toward the end of his Australia visit, Lederberg arranged for Gus Nossal to join him in his new department at Stanford. Josh (as Lederberg liked to be called) had already appointed Len Herzenberg to the department and had arranged for both Gus and Len to arrive at Stanford around the same time (late 1959/early 1960). Being very new in a newly arrived medical school, the Genetics Department was in administrative chaos when Len, with Lee and the children, arrived in Palo Alto. Len asked Lee to come back to work and help him do the paperwork he needed to get his laboratory up and running. It was to be a short-term job. However, Lee wound up staying on as a research assistant (technician, as they were called then), ultimately getting promoted stepwise to her current faculty position in Genetics.

Initially, Len and Gus were located in borrowed space in a lightly constructed Applied Physics building that did not have any air conditioning. Len had received his $\mathrm{PhD}$ at Caltech under the tutelage of several future Nobel Prizewinning geneticists and had spent 2 years with Jacques Monod working on the lacZ operon [4] followed by 2 years in Harry Eagle's NIH laboratory helping to develop methods for culturing mammalian cells (a new art at the time) [5]. He was really eager to get going and establish mutagenesis and selection methods needed to open a study of mammalian cell genetics. He had already cells. He had established cell lines with selectable drug markers while at the NIH and sent for these as soon as he had an incubator to put them in. However, an October heat spell raised the laboratory temperature above $100^{\circ} \mathrm{F}$, and the incubator temperature followed suit, cooking the cell lines beyond recovery. Fortunately, there was still another set of cells at the NIH, which prudently was shipped a month or two later, after the Herzenbergs and Gus Nossal were established in the new Genetics laboratory space in two windowless laboratories in the basement of the main School of Medicine building.

The initial closeness Len, Lee and Gus developed in the first building began a long tradition of mutual learning and teaching about immunology and developing its relationship to genetics and cell biology. Operating as it did in the newly built Stanford Medical School campus, and fed by new appointments and recruits from Genetics and other departments, this group soon grew to a critical mass that established the base for what we now know as Stanford Immunology.

In the sections that follow, we outline (as we remember it) some of the early immunology research that followed the Medical School's move to the Stanford campus. We do not offer this remembrance as a complete, or even nearly complete history. Rather, we hope the reader will see it as 
reminiscences that bring the flavor of the early years into focus.

\section{Early studies of H-2 MHC antigens}

Just before coming to Stanford, Len Herzenberg initiated conversations with George Snell at the Jackson Laboratories about developing antibody-based methods to select for genetically determined changes in natural cell surface markers such as the transplantation antigen(s) encoded by H-2 locus (which later morphed into the MHC). Snell, who was later awarded the Nobel Prize for his transplantation and MHC work, thought Len's idea was perhaps workable and offered to provide small amounts of anti-H-2 antisera to use for complement-dependent selection of loss variants. However, since Snell's laboratory could only spare small amounts of these antisera, and since shipping small amounts of antisera was difficult at the time, practicality demanded that the antisera be produced at Stanford. Lee had to ask Gus Nossal to teach her how to harvest tissues from mice, use them to immunize $\mathrm{H}$-2 incompatible animals and then bleed the recipient mice and assay for success.

This was Lee's (and Len's) introduction to working with mice-she says, "all I knew about mice at the time was that my aunt stood on a chair when one ran across the room." However, with able guidance from Gus, she soon had anti-H-2 antibodies that Len and Howard Cann, their first fellow, successfully used to select for H-2 loss mutants in a mammalian cell line growing in culture [6]. In addition, while generating the anti-H-2 antisera, Lee recognized that multiparous female mice bred to males carrying a different MHC consistently produced antibodies to the male $\mathrm{MHC}$, a finding that led to her first independent publication [7] and opened a long-term research liaison with Robert Goodlin in the Stanford Department of Obstetrics and Gynecology.

Len's interest in using $\mathrm{H}-2$ antigens as markers for studying the genetics of somatic cells rapidly led him to realize that no one at the time really knew the biochemical nature of the $\mathrm{H}-2$ molecules (antigens) that decorated the mouse cell surface. In fact, at the time, Nobelist Peter Medawar had gone on record that they were made of (or associated with) DNA, although others thought they were carbohydrates, proteins or some combination thereof. Len resolved this issue with a biochemical study that definitively established that anti-H-2 antibodies, including those Lee produced with Gus Nossal's help, recognize determinants on proteins that co-isolated with cell membrane lipids [8]. Collectively, these findings opened the way to thinking constructively about the genetics of transplantation immunity, a subject much discussed in the early years at Stanford (see below).
Basic mechanisms in cell-producing antibodies

When Gus and Len moved from their temporary quarters to the main Medical School building, Lederberg assigned them to adjoining laboratories in Genetics space in the basement of what is now the Medical School Alway building (aptly named for Robert Alway, Dean of the Medical School and a strong supporter/architect of the academic growth going on at the time). Len was particularly pleased that Biochemistry was now just upstairs, in particular giving him easy access to Melvin Cohn, who had been a close colleague of Jacques Monod and who had recently taken a strong interest in the genetic mechanisms operating in the mammalian immune system.

As Len and Gus settled into their new labs, Gus was joined by Finnish scientist Olli Makela and the two worked together, using micromanipulation to isolate and test the specificity commitment of the antibodies produced by individual antibody-producing cells. Based on the earlier work, Lederberg, Nossal and Makela expected to find that each cell produced antibodies specific for only one of several bacteriophage antigens used in combination to immunize the cell donors. Mel Cohn, in the Kornberg Biochemistry Department, took the opposing position, i.e., that a single cell would make antibodies to two distinct antigens. Mel posed the challenge, and as Sherlock Holmes would say, the game was afoot. Ed Lennox joined the argument on Mel's side, resulting in a great deal of friendly bantering as the experiments proceeded. Ultimately, Nossal, Makela and Lederberg won, reproducing and extending the findings in the original Lederberg-Burnet-Nossal paper, and firmly establishing the idea that somehow immunization resulted in the selection and expansion of individual cells that were each genetically committed to produce only a single antibody specific for an individual antigenic determinant [9].

With this upstairs-downstairs banter going on, immunology studies in the Genetics Department began to draw substantial interest. Josh stirred the pot by inviting Swedish cancer immunologists George and Eva Klein to join the department as visiting professors in Genetics, and by bringing London immunologist N. Avrion Mitchison for a prolonged visit in which he worked in a laboratory next to the Herzenbergs' and thus just down the hall from Gus and Olli. In retrospect, the immunology "power" in that little basement corridor was awesome, but to this group, it just was themselves as close friends, young scientists who loved talking about genetics and immunology both in and out of the laboratory.

Hal Holman, who also loved talking about immunology when he was not "on the wards," often came to chat, bringing a clinical perspective into the cozy corridor. Hal introduced two medical residents, Robert Mishell and 
Henry Wortis, who essentially joined the Herzenberg lab. Leon Rosenberg, who was appointed by Sid Raffel to Medical Microbiology, also visited quite often and wound up recruiting Len and Lee for a collaboration with him and Dora Tachibana on a genetically deficient mouse that did not produce one of the complement components [10].

Henry Wortis added more details about those early days at Stanford. "Hal had a small laboratory on the first floor of the hospital where I settled in with another fellow, Gordon Sharp. Gordon and I shared clinical duties as well as the lab. We were joined soon by Dick Wistar. I still have vivid memories of the three of us traveling rapidly through the hospital hallways, Hal in the lead, with our four white coats flapping behind. We were all over six feet and at the time must have appeared as a formidable phalanx.

Hal also had another larger laboratory in the basement. Officially, that is where I was to have a home. But it was isolated and lonely down there and I wandered next door for company. And there I was welcomed by Len and Lee. The place was jumping. At the time I arrived, Bob Mishell had just gone north to establish his own lab. John Minna, John Wunderlich and Bob Erickson were already in the laboratory or arrived shortly after I did. Irv Weissman was a medical student, intensely interested in immunology and genetics, but was not in the Herzenberg laboratory at the time. Noel Warner arrived as a fellow within the year. There was also a stream of visitors; Peter Medawar was one of the visitors, and we met through Len. Sir Peter agreed to take me on for a second postdoctoral period at Mill Hill in London."

Interactions abounded! Radiologist Henry Kaplan [11, 12], who would soon develop a functional therapy for Hodgkin's disease, was very excited about how cell-based immunology and genetics intersected with medical practice. He introduced a young surgeon (later to lead in cardiac transplantation) named Norman Shumway into the group, thereby extending its focus to include the mechanisms involved in transplant rejection and hence to recognition mechanisms involved in $\mathrm{H}-2$ (MHC) graft rejection/acceptance. Graft acceptance/rejection as it occurred in male/female incompatibility also was of interest to Irving Weissman, a first-year medical student. Irv had studied male/female histoincompatibility as a high school and college student in Montana with Ernst Eichwald (see below). Irv began working in the Herzenberg laboratory together with fellow students Robert Ericson and Harvey Ozer. The latter two remained to work on MHC issues, but Irv soon moved to Henry Kaplan's laboratory, where there was funding that he could use to pursue studies focused on male/female antigenic differences and their use as a model system to understand natural and induced transplantation tolerance and the role of the thymus.
All of this came together in a course and later a seminar that Josh asked Len to organize on what might now be called "immune recognition mechanisms" or the "cellular basis of immune responses." However, the understanding of the cells that were actually involved in antibody production was far more primitive. Plasma cells had been recognized microscopically as antibody-producing cells, and lymphocytes were recognized as the antecedents of plasma cells. However, the separation of lymphocytes into $\mathrm{T}$ and $\mathrm{B}$ cells, to say nothing of the multiple subdivisions within these groups, was several years off, as was the whole concept of regulatory immunology. Stanford immunologists were major players in the establishment of these functional subsets. However, this work falls beyond our history mandate here.

Regular attendees at the early immunology seminars came from departments all over the medical school and included medical students working on immunology-related projects in laboratories in genetics, radiology, biochemistry, medical microbiology, medicine. Josh attended almost all of these lectures, as did all of the immunology-oriented visitors in the Genetics Department, including Walter Bodmer after his arrival (see below). Henry Kaplan, Sid Raffel and George Feigen were regular attendees. Mel Cohn was also there and could always be counted on for innovative arguments. Norman Shumway and Avram Goldstein also attended on occasion. Immunology had indeed become a vibrant cohesive force in the medical school!

\section{Immunoglobulin genetics}

Around this time, Mel Cohn decided to leave the Stanford Biochemistry Department to help in the establishment of the Salk Institute. He asked Len if John Wunderlich, then a second-year medical student, could join Len's laboratory but continue to work on the project that Mel had assigned to him, i.e., the production of alloantisera to detect alloantigens present on mouse immunoglobulins. Len was pleased to have the opportunity to mentor John and took to both John and the project like a duck to water. John readily agreed to shift the antibody detection assay from one based on phage neutralization to the simpler use of agar gel immunoprecipitation (Ouchterlony analysis, as it was called) to detect reactivity with the immunizing immunoglobulin. This allowed ready detection of what we now know as allotypic differences between BALB/c- and C57B1/6-encoded IgG2a molecules [13]. Thus, began the Herzenberg's long romance with the murine IgH chromosome and the allelically encoded allotypic differences in the constant regions of the various immunoglobulin isotypes. 
The primary focus in this early work was clearly genetic rather than immunologic. It started by searching for methods to distinguish genetic differences (allotypes) between antibodies encoded by two distinct mouse strains (BALB/c and C57B1/6). Later, as distinct IgH isotypes were identified, the work expanded to defining and mapping the genes that encoded each of the $\mathrm{IgH}$ constant regions (functional subset studies were still a ways off). Contrary to common current belief, the demonstration that these IgH-encoding genes were closely linked in the newly named $\mathrm{IgH}$ chromosome region occurred well before the molecular era, and also well before the $H-2$ chromosome region was dissected into a multiplicity of loci and renamed the MHC. In fact, as Jan Klein once pointed out to Lee Herzenberg, the concept of the MHC was modeled after the IgH chromosome region, not the reverse. In any event, by 1964, the Herzenberg laboratory had clearly established the mouse IgH chromosome region as containing a series of linked loci individually encoding $\mathrm{IgH}$ for the various isotypes, and Henry Kunkel had done the same for the human IgH chromosome region, thus together establishing a genetic principle that underlies most of modern Ig genetics [14].

Interestingly, although Len used immunological tools in his work and focused much of his early work on genetic studies related to the immune system, he always read much more widely, keeping an eye for relevant new ideas and methods (Len always read the methods section of a paper before starting on the introduction). He avidly followed the single-cell immune function work being done "next door" by Nossal, Makela and Mitchison, but he found the micromanipulation and other microscope-based technologies in use at the time too cumbersome and too subjective to be practical for making immunology into a viable science. Thus, it is not surprising that when Lederberg developed an interest in space biology and set up his exobiology engineering group next door to the Herzenberg laboratory (in the basement laboratory that Mitchison had occupied), Len gravitated toward the engineers and began thinking about whether/how new technologies could be used to identify, viably sort and functionally characterize the various cells in the immune system.

The Stanford Immunology community and the development of the FACS

The history of the development of flow cytometry at Stanford in the 1960s, and the formative role of the Herzenberg group in this development, has been told often and at length [1518]. However, the telling of this tale does not perhaps do justice to the key contributions that Stanford immunologists have made over the years to the development of the technology. Measured in terms of "nuts and bolts," there is

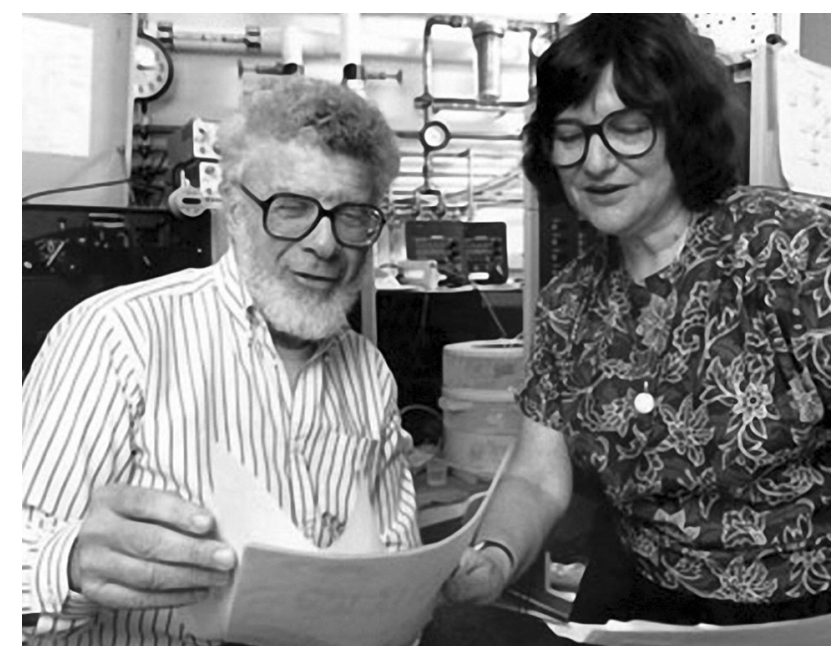

Fig. 1 Len and Lee Herzenberg (ㄷ Stanford News Service, 1987. Used with permission)

perhaps not too much to say. However, technology development only succeeds when it speaks to the needs of the potential users. Thus, in addition to those who contributed directly to the engineering accomplishments (Richard Sweet, David Parks, Wayne Moore, Tom Nozaki and others) $[19,20]$, credit belongs to the Stanford basic and clinical immunologists who were working and socializing with the engineers and scientists in the Herzenberg laboratory throughout the time the fluorescence-activated cell sorter (FACS) was being developed. Using/testing each new capability as it was added, and "voting with their test tubes" as to which capabilities were key. The Stanford immunology community played a unique role in making the FACS what it is today. Perhaps this should be said more often.

Of course, the immunology community also benefitted from having access to forefront capabilities and used this access to advantage in a wide variety of studies. Henry Kaplan, who very early recognized the importance of the effort and contributed major funding to it, was among the first users. Nevertheless, it took several years for the technology to mature enough to be really useful in a variety of immunology studies. By the time this happened, the number of people whose work centered in one way or another on the immune system had grown substantially at Stanford, as it had in the national and international research community as a whole.

The Stanford Shared FACS Facility, which the Herzenbergs established, grew together with the Stanford immunology community. Offering expanded facilities and capabilities to meet the growing needs at Stanford, the facility engineers also migrated the new capabilities into the commercial sector, thus making these capabilities broadly available to immunologists and medical scientists everywhere [15-19] (Fig. 1). 
While this was happening, the biomedical side of Len and Lee Herzenberg's laboratory grew and broadened its focus to include the $\mathrm{IgH}$ chromosome region, maternalfetal immune interactions, allotype suppression, the expression $\mathrm{T}$ and $\mathrm{B}$ cell surface markers, molecular studies including the cloning of CD5 and CD8, functional studies with NF-kB and other transcription factors, B cell subset/ lineage studies and, more recently, redox influences in HIV, cystic fibrosis and other diseases. In turn, the needs of these and other Stanford high-dimensional FACS studies continued to drive the development of automated highdimensional flow cytometry analysis software (AutoComp and AutoGate) ${ }^{1}$ - all of this happening in the collaborative style established early in the Medical School history and enthusiastically maintained in the school today.

Len and Lee's immense contributions to immunology have been recognized by many awards and honors, most notably a special Novartis Prize in Immunology in 2004, the Kyoto Prize in 2006, and Len's election to the National Academy of Sciences. Still actively engaged in the laboratory's research at age 81, Len passed away in October, 2013. Lee continues to run the laboratory and to expand the Herzenberg legacy of contributing to the immunology community here and elsewhere and of pioneering advances in FACS technology and in basic and applied immunology research.

\section{Leukocyte antigens, HLA and H-2, transplantation, and genetic control of immune responsiveness and disease susceptibility}

During these early days of immunology at Stanford, a second focus developed: the description of human leukocyte antigens and elucidation of their genetics, key in the discovery of the HLA major histocompatibility gene complex. Studies of genes of the mouse $H-2$ MHC followed, with a focus on the roles of MHC class II in the genetic control of immune responsiveness and disease susceptibility in both mice and humans. This branch in the history of Stanford immunology began with Rose Payne's seminal work and included pioneering contributions from Walter and Julia Bodmer and Hugh McDevitt.

\section{Rose Payne and Walter and Julia Bodmer}

Rose Payne (Fig. 2) had received her PhD in bacteriology in 1937 from the University of Washington and held various short-term positions, including several in bacteriology and as a counselor for women in a Portland shipyard during World War II [21, 22]. In 1948, she was hired as a hematology

\footnotetext{
${ }^{1}$ See Meehan et al. this volume.
}

research assistant in Stanford School of Medicine, then in San Francisco, beginning her work in immunohematology. Red blood cell antigens including ABO and $\mathrm{Rh}$ had already been described, and there were suggestions that other alloantigens on leukocytes (white blood cells) might contribute to transfusion reactions. In 1954, Jean Dausset discovered that some sera from transfused patients contained antibodies that agglutinated leukocytes, and Rose published her first studies of these leukoagglutinins in 1957 [23, 24]. In 1958, she made the seminal discovery that sera from multiparous (multiply pregnant) women contained such leukoagglutinins against paternal antigens [25], a finding also made independently by Jan van Rood.

Rose developed an extensive library of these valuable but complex pregnancy sera (some from Stanford families) and set out to understand the genetics controlling the alloantigens the sera recognized. Dausset showed in the early 1960s that these alloantigenic differences affected skin graft rejection, the first indication that they were involved in histocompatibility. Rose, by then a senior scientist, moved to the Stanford campus with the rest of the Medical School in 1960. Her efforts to understand the leukocyte antigens were soon bolstered by the arrival of two new colleagues.

Walter Bodmer had studied in math at Cambridge, receiving his $\mathrm{PhD}$ with R.A. Fisher, the great statistician and geneticist. He learned of Fisher's elegant work on the $\mathrm{Rh}$ system, and after completing his $\mathrm{PhD}$ analyzed the interaction between linkage and selection applied to two closely linked loci-studies that would prove relevant to his subsequent work on what eventually became known as the HLA complex [26]. He came to Stanford in 1961 to do a 1 year postdoc with Joshua Lederberg to work on DNA transformation of bacteria and to learn molecular biology.

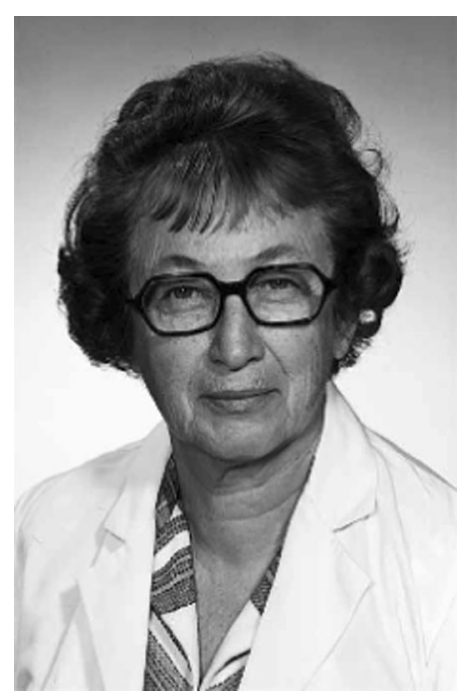

Fig. 2 Rose Payne (ㄷ) John Wiley and Sons, 2002. Used with permission) 
Walter, Julia and their young children arrived just after Gus Nossal left; in fact, Esther Lederberg helped them acquire the Nossals' house, car and, most importantly, their baby sitter list! [27]. Walter was also attracted to Stanford by Len Herzenberg's early work in somatic cell genetics, and his first introduction to immunology came from attending the Herzenbergs' informal seminars at their home. In 1962, Josh appointed Walter acting assistant professor so he could teach genetics to the medical students. Walter heard Rose talk about her work on leukocyte blood groups and enlisted her help in teaching the genetics course. In turn, Rose recognized the value of having an experienced statistician and geneticist help her dissect the complex serological data she was collecting; thus began a very productive collaboration that lasted decades.

As Walter was busy learning molecular biology, Julia was enlisted to help Rose with her data. Julia, who had experience in statistics from her studies at Oxford and a research job in statistical economics, took on analysis of Rose's data as a break from caring for their three young children. This was initially an unpaid position, but that was remedied by a joint grant Walter obtained with Math professor Sam Karlin for population genetic studies. Having had some programming experience while at Cambridge, Walter realized that computer analysis could greatly facilitate understanding the serological data, an approach that had already been taken by Van Rood. Julia took a programing course and wrote her first program to analyze the data from Rose and van Rood using Stanford's young but excellent (even for that time) computer facilities. This quickly revealed three clusters of leukocyte antigen (LA) reactivities: Rose's LA1 (eventually renamed HLA-A1) and LA2 (eventually renamed HLA-A2), and van Rood's 4a (eventually renamed HLA-BW4, encoded by a second locus). Despite the complex multispecific sera and the primitive leukoagglutinin assays initially used for typing, Rose and the Bodmers' comparisons of serum reactivities, some simple absorption assays and limited analysis of family data led to their first paper, which defined alloantigens controlled by what they called the LA locus (eventually called HLA-A) [28].

Rose Payne and the Bodmers continued to be leading players in the subsequent rapid progress in defining leukocyte antigens, their genetics and their roles in histocompatibility. Their willingness to freely exchange sera and data helped to foster a remarkable spirit of collaboration among the early workers, including van Rood, Bernard Amos, Paul Terasaki and a few others. In 1964, they also helped to found the International Histocompatibility Workshops, which met regularly to share results, reagents and techniques. At these workshops, Rose, Walter and Julia played key roles in preparing summaries of the work that was presented and, through the Nomenclature Committee, in developing the nomenclature for describing the antigens and their genetics.

It was soon realized that the HLA antigens played a role in organ transplant rejection; human kidney transplantation was just beginning in the 1960s. Early on, Rose studied the effects of the alloantibodies in nonfebrile transfusion reactions, and later participated in tissue typing for kidney transplants at UCSF with Herb Perkins and at Stanford with Sam Kountz [21]. She, Walter and Julia did the tissue typing for the early heart transplants carried out at Stanford by Norm Shumway (Walter remembers chatting with Shumway while he was having a drink of milk to calm his ulcer before he went into the theater to do the first transplant operation [27]). Rose also performed studies showing that HLA-A alleles varied among racial and ethnic populations. She later helped to describe HLA-D antigens. Only a research associate during these pioneering studies despite being one of the most respected investigators in the department, Rose was finally appointed Professor of Medicine in 1972, only 3 years before she retired as professor emerita. In an interview posted on the web site of the American Society for Histocompatibility and Immunogenetics about that appointment, she recalled "I had never asked for anything. Then 1 day, I decided I was old enough and established enough. So I marched right in and asked" [29]. She remained active for another 15 years, and her data and insights continued to be crucial to the rapidly growing HLA field. Called by many friends and colleagues in the field "the Mother of HLA" [22], Rose was recognized by numerous awards, including the establishment in her honor of the annual Rose Payne Distinguished Scientist Award by the American Society for Histocompatibility and Immunogenetics (of which Walter was the first recipient).

Through the 1960s, Walter and Julia Bodmer worked with Rose at Stanford in deciphering the genetics of leukocyte antigens. In 1966, Walter was promoted to associate professor with tenure, with promotion to full professor just 2 years later, and the Bodmers established their own laboratory in Genetics, engaged in studies of leukocyte antigens, somatic cell genetics and population genetics (with Sam Karlin) [27]. Walter developed an improved cytotoxicity assay, cytofluorochromasia, for testing the reactivity of the alloantisera, using cells stained with fluorescein diacetate (FDA) [30]. This assay was based on the previous finding by Boris Roitman and Herzenberg fellow Ben Papermaster that living cells stained with FDA retained fluorescein and thus were rendered fluorescent and detectable under the fluorescence microscope, while dead cells did not retain the stain - this was the basis for the first sorting of fluorescent cells with the prototype fluorescenceactivated cell sorter [20]. Further analyses of Rose's sera using this new assay (which in modified form is still in use today) led to identification of the HL-A and 4 loci, as 


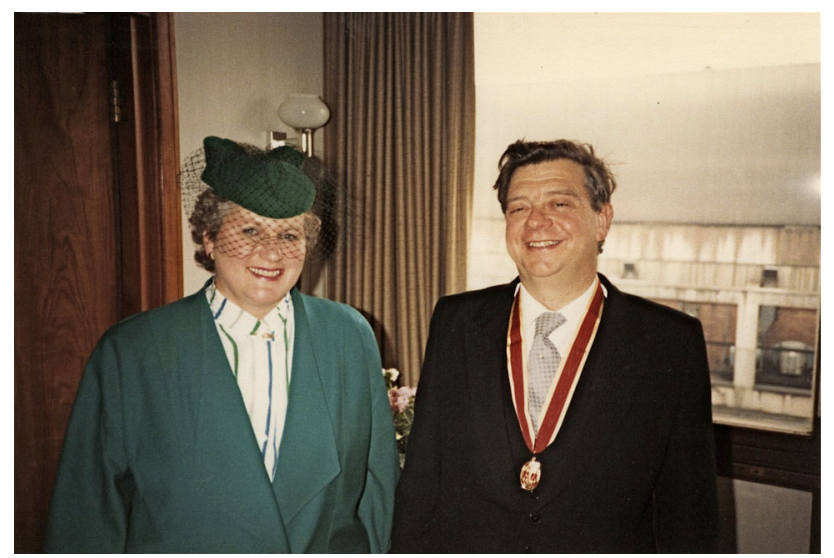

Fig. 3 Julia and Walter Bodmer, after he received his knighthood (C) Walter F. Bodmer, 1986. Used with permission)

mentioned above [26]. The tremendous genetic polymorphism of HLA made it an obvious candidate for human population genetics studies, and to facilitate the first field studies, on African pigmies, Walter worked out valuable techniques to keep leukocytes alive for shipment back to the laboratory.

In 1970, Walter and Julia returned to England where they both had professorial appointments at the Imperial Cancer Research Fund (ICRF) in London until 1996 when they moved to Oxford. They continued to make pivotal contributions to HLA and to human genetics more broadly. Both have been recognized by many awards and honors. Walter was appointed fellow of the Royal Society, was knighted in 1986 and received the Royal Medal from the Royal Society in 2013. Sir Walter continues to be active in human genetics research. Julia was elected Fellow of the UK Academy of Medical Sciences and an Honorary Fellow of the Royal College of Physicians. She passed away in 2001 (Fig. 3).

\section{Hugh McDevitt}

A major focus on what are now called MHC class II genes and their functions started at Stanford in 1966 when Hugh McDevitt arrived as an assistant professor in the Division of Immunology in the Department of Medicine. After completing his undergraduate degree in biology at Stanford, Hugh attended Harvard Medical School and then did his medical training in New York and Boston. After serving two required service years in the Army Medical Corps, he returned to Harvard in 1959 where he began his career in immunology as a postdoc with Albert Coons, who had invented the fluorescent antibody technique in the 1940s. Hugh then joined the laboratory of John Humphrey at the National Institute for Medical Research at Mill Hill outside London, with the goal of testing the instructive theory of

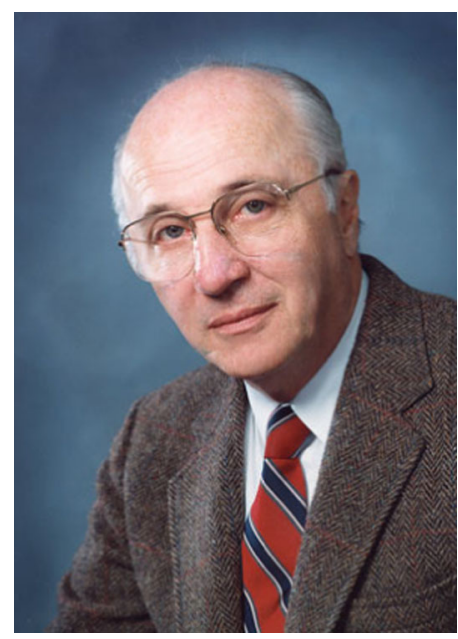

Fig. 4 Hugh McDevitt (C Stanford School of Medicine, 2002. Used with permission)

antibody specificity by determining whether an antigen could be found in plasma cells [31]. The antigen was a branched polypeptide antigen $(\mathrm{T}, \mathrm{G})-\mathrm{A}-\mathrm{L}$ (which has a backbone of poly-L-lysine, with side chains of alanine to which were attached short random sequences of tyrosine and glutamic acid), one of several related antigens synthesized by the Israeli immunologist Michael Sela for the study of antigenicity. Although (T,G)-A-L was immunogenic in rabbits at the Weizmann Institute in Tel Aviv, Humphrey had been unable to generate an antibody response in his Sandylops rabbits. After arriving, Hugh showed dramatic differences in antibody responses in different strains of rabbits, suggesting genetic variability in antibody production, which he confirmed in crosses and backcrosses among these noninbred strains. This initial evidence for genetic control of immune responsiveness set the path for Hugh's research for the rest of his career (Fig. 4).

Hugh pursued the genetics controlling antibody responses to (T,G)-A-L in mice because of the availability of inbred strains. Fortunately, the strains available at Mill Hill, CBA and C57, were found to differ markedly in their antibody responses to (T,G)-A-L; C57 was a responder, CBA a nonresponder and the F1 an intermediate responder. The study was extended to Sela's other branched polypeptides, including $(\mathrm{H}, \mathrm{G})-\mathrm{A}-\mathrm{L}$, in which tyrosine was replaced by histidine; $(\mathrm{H}, \mathrm{G})-\mathrm{A}-\mathrm{L}$ gave the opposite response pattern, in that $\mathrm{CBA}$ mice responded but $\mathrm{C} 57 \mathrm{did}$ not. The ability to respond segregated in backcross mice as a single dominant trait but the location of its gene was unknown. These studies were among the first to show the genetic control of immune responsiveness [32, 33].

After arriving at Stanford, Hugh heard from Lee Herzenberg that the Jackson Laboratory had inbred strains of mice on several different backgrounds that were congenic 
for various $H-2$ haplotypes but varied in their genetic background [31]. As there was no expectation that immune responsiveness was controlled by $H-2$, the results with these congenic strains were a surprise: responsiveness to (T,G)-A-L segregated with the $H-2^{b}$ haplotype, i.e., immune responsiveness was controlled by the $H$-2 complex [34]. While this finding initially was controversial among immunogeneticists working on $H$-2, Donald Shreffler, Jan Klein, Jack Stimpfling and others shared with Hugh the intra- $\mathrm{H}-2$ recombinant strains they were generating to enable mapping of the gene. The responses in these recombinant strains, along with the responses of progeny of four-point crosses, eventually yielded the striking result that the gene controlling responsiveness to (T,G)-A-L and $(\mathrm{H}, \mathrm{G})-\mathrm{A}-\mathrm{L}$, which Hugh named Ir-1 (immune response gene-1), mapped between $H-2 K$ and $S s$ (a gene controlling a polymorphic serum protein, now known to be C4) [35]. These findings led to the definition of the $I$-region, between the $K$ and $S$ regions in the mouse $H$-2 complex.

While doing the genetic studies, Hugh was also pursuing the cell type(s) in which $I r-1$ was acting to control immune responsiveness; arguments were made for both $\mathrm{B}$ and $\mathrm{T}$ cells. At the suggestion of Len and Lee Herzenberg, Hugh set up a collaboration with Marvin Tyan at the Hunter's Point naval radiation research laboratory to develop a cell transfer protocol for determining the cell type that controlled responsiveness. They showed that spleen cells from $(\mathrm{CBA} \times \mathrm{C} 57) \mathrm{F} 1$ responder mice could transfer responsiveness to (T,G)-A-L to low responder CBA mice [34]. Determining whether $\mathrm{B}$ or $\mathrm{T}$ cells was responsible was problematic because of GVH reactions, and as we know now, because MHC class II restriction limits the interactions between helper $\mathrm{T}$ cells and $\mathrm{B}$ cells from mice differing in MHC class II alleles [31].

These functional studies were overtaken by studies in several laboratories, including Hugh's, with alloantisera generated in $\mathrm{H}-2$ recombinant strains that revealed a set alloantigens controlled by $I$-region genes: the immune response-associated (Ia) antigens [36, 37]. The Ia antigens (now called MHC class II proteins) were shown to be on B cells, not T cells, and Hugh's laboratory eventually confirmed that $I r$ gene function in controlling responses was a property of B cells, not T cells $[31,38]$. During the 1970s, key studies by Green, Shevach, Rosenthal and others demonstrated the requirement for Ir-gene compatibility (MHC class II restriction) in the activation of helper T cells by macrophages (summarized in ref. 31). Of course, we know now that MHC class II (and class I) molecules bind a diverse (but not universal) range of peptides, generating peptide/MHC complexes of enormous complexity, and that different allelic forms of MHC class II proteins bind subsets of peptides and control T-cell responses through the differential effects of peptide/MHCII complexes on T-cell selection in the thymus and on $\mathrm{T}$ cell activation in the periphery.

Soon after his description of the genetic control of immune responsiveness to branched polypeptide antigens in mice, it occurred to Hugh that MHC genes might control susceptibility to diseases, including infectious diseases and autoimmunity. Rose Payne and Walter Bodmer were immersed in their studies of HLA genetics, and Walter agreed to collaborate to determine whether HLA is associated with systemic lupus erythematosus (SLE), an autoimmune disease familiar to Hugh, a practicing rheumatologist. The study of HLA genotypes in SLE patients was carried out with the help of Carl Grumet, who had been an intern and resident at Stanford and returned in 1969 as a postdoc in Hugh's laboratory (Carl joined the faculty in 1971, worked closely for many years with Rose Payne on HLA typing, and was the first director of the Stanford Blood Center). The study showed a significant association of SLE with HLA-B8 and B15, the first evidence of association between the MHC and disease susceptibility [39]. These findings prompted Hugh and Walter to write an insightful article describing the implications of the results and suggesting that they might extend to other autoimmune diseases [40], which was subsequently confirmed for many other autoimmune diseases.

Hugh and his laboratory went on to make important discoveries about how MHC class II polymorphism controls immune responsiveness and disease susceptibility in mice and humans, including demonstrating the roles of polymorphic MHC class II amino acid residues in controlling antigen presentation and identifying novel features of type I diabetes-associated MHC class II alleles-the $I-A \beta^{g 7}$ allele of the NOD mouse and HLA-DQ alleles in humans-responsible for their association with that autoimmune disease [41, 42].

Hugh served as chief of the Division of Immunology in the Department of Medicine, and after moving to the Department of Microbiology and Immunology he became chair of that department. He became professor emeritus in 2008. His important contributions to immunology and medicine have been recognized by many awards and honors, including election to the National Academy of Sciences and the Institute of Medicine.

\section{The next cohort}

The early strength in immunology that was established at Stanford in the 1950s and 60s was expanded by the addition to the faculty of three key immunologists who joined the faculty in the late $60 \mathrm{~s}$ and early $70 \mathrm{~s}$. The research interests of all three-Irving Weissman, Sam Strober and Ron Levy-grew out of their early research experiences, enhanced by their many interactions with colleagues at Stanford. 
Irving Weissman

Irv Weissman had become interested in immunology as a high school and college student in Great Falls, Montana, through work as a student assistant with Ernst Eichwald at the Montana Deaconess Hospital (which later became the McLaughlin Research Institute) [43]. Irv worked on histocompatibility, including the role of the male-specific antigen now known as $\mathrm{H}-\mathrm{Y}$ in rejection [44]. He became intrigued by the emerging understanding of tolerance, which could be induced by transfer of allogeneic cells into embryos or neonates. Hearing of the new 5-year medical curriculum at Stanford, designed by Avram Goldstein and Lyman Stowe, where the students had a half day every day for 3 years to do research while completing the basic sciences part of medical school, Irv decided to apply, even though he had only completed 3 years of college (the third at Montana State, where he took graduate courses in genetics and evolution from David Skaar, himself a student with Lederberg and Tracy Sonneborn). Despite a modest grade point average, Irv was duly admitted to Stanford School of Medicine in 1960, entirely on the basis of his publications according to a member of the admissions committee [45].

Irv recalls arriving at the Medical School a few days early, and on the evening of his arrival, he wandered into the Genetics corridor, where he met Av Mitchison, who was about to leave for the day, as always wearing bedroom slippers and a plaid shirt. Irv and Av immediately connected, as Av knew of Eichwald. Irv, together with Eichwald, had just published a magnum opus on H-Y [44], including evidence that it was the same in all mouse strains, was present on normal and neoplastic tissues, and that mouse strains in which the females could not reject male skin lacked genetic "reactivity" rather than tolerance via cohabiting a uterus with male fetuses. Av suggested Irv begin work with the Herzenbergs and, with Av's support, was soon accepted into their lab. "It was a magic time" Irv says. The center of immunology debates took place at the popular weekly evening "seminars" that Len and Lee organized at their home, and Irv benefitted from the active immunology community at the time, which as mentioned above included Av Mitchison (who was working on tolerance), Gus Nossal, Ollie Makela, George and Eva Klein, Mel Cohn, and of course Len and Lee Herzenberg, all of whom regularly attended the weekly seminars at the Herzenberg home.

Ultimately, Irv's interests in tolerance and its relation to the development of the immune system seemed less related to the immunogenetics focus of the Herzenberg laboratory. Therefore, Irv sought an opportunity in a more organismal oriented lab. Henry Kaplan, who had published on H-Y and the role of the thymus in the development of T-cell lymphomas induced by whole-body ionizing radiation, agreed to let Irv follow his nose in a laboratory he shared with a new Assistant Professor, Saul Rosenberg. Henry had co-developed the linear accelerator to deliver high-dose radiation and had shown that Hodgkin's Disease, a lymphoid neoplasm, predictably spread from one lymph node to the next via efferent lymphatics and could be cured by irradiating not only that node, but also the next set of draining nodes, by a technique later called total lymphoid irradiation, or TLI, which Irv later showed was the main reason Hodgkin's patients lacked cell-mediated immunity [45].

In that first year in the lab, 1961, three major findings changed Irv's approaches to tolerance and the thymus: the demonstration by Till and McCulloch that bone marrow contained cells that could make multilineage blood cell colonies in the spleen; the finding by JFAP Miller that neonatal removal of the thymus not only prevented lymphoma development (on the same track as Kaplan), but also led to immune deficiency and a wasting disease; and the finding by Gowans that lymphocytes recirculated from blood to lymphoid tissues and thence via the thoracic duct to the bloodstream again and that these lymphocytes were immune competent [46]. Hearing James Gowans talk about his finding that small thoracic duct lymphocytes transfer immune functions, Irv decided to head to Oxford to work with Gowans on a student traineeship. There he developed radiolabeling techniques he used to show that small numbers of bone marrow cells seed the thymus and that large numbers of cells leave the thymus to enter lymph nodes and spleen in what become the T-cell domains in those tissues [47].

Irv completed his MD, stayed at Stanford as a research associate, and was appointed assistant professor of Pathology in 1969. Following a scare in 1973 when a number of Stanford immunologists reported to David Korn, his department chair, that they could not support his promotion to tenure, Irv nevertheless was promoted the next year [45]. During this time, the different roles of $\mathrm{T}$ and $\mathrm{B}$ cells in antibody responses were being defined by Miller, Mitchell and others, and Irv and his colleagues pursued the migratory pathways of B and T cells. Irv's laboratory developed approaches for tracking $\mathrm{B}$ and $\mathrm{T}$-cell migratory patterns after transfer, characterized the homing patterns of lymphocyte subsets, and eventually identified, cloned and showed the functions of CD62L and integrin a4ß7 lymphocyte adhesion proteins, which control tissuespecific homing (see references in ref. 43).

Beginning in the late 1970s, Irv pursued his longstanding interest in the ontogeny of the immune system by beginning the search for B-cell precursors in addition to his studies on thymus cell maturation, using monoclonal antibodies and the FACS to isolate hematopoietic 
subpopulations from bone marrow. Their developmental potential was tested in Till-McCullloch spleen colonies, in Whitlock-Witte cultures with stromal cells, in thymic colony formation, or following cell transfer in vivo for longterm multilineage maturation. These studies led to the pivotal discovery of the hematopoietic stem cell (HSC), the only self-renewing hematopoietic cell $[48,49]$.

Weissman formed a company, SyStemix, where his team isolated human HSC, found that these purified cells taken from cancer patients with bone marrow metastases were cancer-free, and transplanted many patients with their own HSC following high-dose chemotherapy [45]. Irv and Judy Shizuru went on to show in mice that HSC transplants, which are $\mathrm{T}$ cell free, cannot cause $\mathrm{GvH}$; when engrafted they induce permanent immunological tolerance to any tissue from the HSC donor. They demonstrated that, when engrafted, HSC from mice lacking the genetic predilection for autoimmune type 1 diabetes or lupus cured these autoimmune diseases in the mice that suffer from these diseases [50].

The general method for studying stem cells that Irv developed led him and his team to isolate many other stem cells, including human central nervous system stem cells, now in clinical trials on a number of brain, spinal cord and eye diseases [45]. In 2000, his group isolated human leukemia stem cells, which led to the discovery of a number of cancer targets, including CD47, a "don't eat me" cell surface molecule found on all cancers, which counteracts the cell surface programed cell removal molecules that arise during preclinical development of cancers [51]. He has led a team to produce function blocking anti-CD47 antibodies, which are about to enter clinical trials this year.

Since then, Irv's large and active laboratory has continued to identify the various cellular intermediates and developmental pathways leading from HSC to mature leukocyte populations [52]. They have also pursued the identification and characterization of other stem and progenitor cells [53]. Irv has received numerous awards and honors, including election to the National Academy of Sciences. He is currently Director of the Stanford Institute for Stem Cell Biology and Regenerative Medicine.

\section{Sam Strober}

From the time he entered Harvard Medical School, Sam had an interest in organ transplantation and joined the laboratory of Joseph Murray, who pioneered kidney transplantation-for which he later earned the Nobel Prize. ${ }^{2}$ Seeking to understand the immune basis for rejection, and perhaps eventually develop an approach for inducing

\footnotetext{
2 This is a short summary of Sam Strober's article in this issue on the history of his research [54].
}

tolerance to transplanted organs, Sam showed that rejection of organ transplants in dogs could be enhanced by previously sensitizing the donor against cells from the recipient. To continue these studies in mice, he did a research fellowship with James Gowans at Oxford, where he overlapped with Irv Weissman. Sam repeated the dog findings in rats, demonstrating that lymphocytes could be sensitized to an organ by passage through a donor kidney. After completing his MD and training, he visited Stanford and was persuaded by the strong immunology community (Irv Weissman, Hugh McDevitt, Hal Holman, and Len and Lee Herzenberg) to accept a faculty position in the Division of Immunology and Rheumatology, which he began in 1972.

Sam's initial work focused on B cells and B-cell lymphomas, and he began a collaboration with Henry Kaplan to characterize the immune impairment of Hodgkin's patients who had received TLI (irradiation of peripheral lymphoid tissues while protecting the bone marrow). Finding that those who had received TLI were immunosuppressed as well as cured of their disease, Sam realized that this might be an approach for inducing transplantation tolerance and worked with Kaplan and others to establish a mouse TLI model. They showed that unlike full-body irradiation, TLI followed by fully MHC-mismatched bone marrow transplantation led to stable mixed bone marrow and blood chimerism without the development of GVHD [55]. Strikingly, these animals were then tolerant to organs from the bone marrow donors [56]. Additional studies by Sam and his colleagues led to the optimization of the tolerizing protocol (including adding treatment with antithymocyte serum, ATS), identification of regulatory cells (especially NKT and Treg cells) that contribute to tolerance induction, and application to humans. The protocol, which prevents GVHD in bone marrow transplant recipients, has been used successfully to eradicate leukemias and lymphomas in patients not able to receive other conditioning regimens [54].

Most exciting has been the application of the TLI-based conditioning regimen to induce tolerance to kidney transplants. Several protocols have been tested in recent years for inducing tolerance to transplanted kidneys. In a protocol begun in 2005 using a posttransplant treatment regimen involving TLI and anti-thymocyte globulin (ATG) following transplantation of HLA-matched kidneys from living donors plus hematopoietic cells, almost all of the patients developed mixed chimerism, and $80 \%$ of the patients were able to be withdrawn from immunosuppressant drugs within the first year without subsequent rejection episodes during the subsequent few years of follow-up [57, 58]. Thus, Sam and his colleagues appear to be on their way to finding the "Holy Grail" of organ transplantation: the ability to induce specific tolerance to transplanted organs and eliminate the need for immunosuppressant 
drugs [54]. Sam has received a number of awards and honors for his work.

\section{Ron Levy}

As a medical student at Stanford Medical School in the mid-1960s, Ron worked with Len Herzenberg on cancer cells in culture. ${ }^{3} \mathrm{He}$ gained further research experience with Israeli immunologist Michael Feldmann at the Weizmann Institute, Steve Rosenberg at the NCI, and as an Oncology Fellow with Saul Rosenberg back at Stanford. Returning to the Weizmann, Ron made antibodies against antibody idiotypes and used them to treat lymphomas in mice, a precursor to his subsequent work with human Bcell lymphomas. He returned to Stanford in 1975 as assistant professor in the Division of Oncology in the Department of Medicine. With the development of monoclonal antibody techniques and the generation in Ron's laboratory of B lymphoma hybridomas producing soluble forms of the lymphoma's membrane immunoglobulin, Ron set out to make anti-idiotypes against each patient's tumor. The first patient thus treated was cured by this mouse antiidiotype antibody [60].

Producing monoclonal anti-idiotypes tailored to and effective for each patient's tumors proved to be a challenge, and Ron turned to other monoclonal antibodies to B cells. A company Ron helped to form, Idec, developed an antibody to CD20 (later called rituximab), and its injection resulted in significant tumor regressions in lymphoma patients at Stanford [61]. Recognizing that therapeutic antibodies work by activating other cells, such as NK cells, to kill the targets, Ron and his colleagues have identified other antibodies that in combination with anti-tumor antibodies lead to enhanced killing of the tumor cells [62]. A major effort in the laboratory has been the generation of vaccines and other agents for activating patient immune responses against their own tumors. A current focus is on injection of activating antibodies and TLR ligands directly into a tumor site; this approach has shown promise in both mice and humans [63, 64]. Ron has been recognized for his contributions to lymphoma medicine with a number of honors, including the King Faisal Prize and election to the National Academy of Sciences and the Institute of Medicine.

\section{Rapid expansion of immunology at Stanford university}

The 6-year period from 1978 to 1983 was a time of considerable expansion in immunology, with eight prominent

\footnotetext{
3 This is a short summary of Ron Levy's article in this issue on the history of his research [59].
}

young immunologists joining the Stanford faculty. Most are currently still at Stanford and continue to play important leadership roles in immunology at Stanford and internationally.

In 1978, Edgar Engleman and Patricia Jones joined the Stanford faculty, Engleman in Pathology and Jones in Biology. Ed received his MD from Columbia University, followed by clinical and postdoctoral training at UCSF and the NIH. He did a second postdoc at Stanford with Hugh McDevitt, during which he contributed to studies of mixed lymphocyte reactions stimulated by HLA-D region-encoded antigens. His research has been on human immunology and focused over the years on T-cell subsets and their regulatory roles, effects of HIV/AIDS on the immune system, roles of NK cells and dendritic cell subsets in immune regulation, dendritic cell-based vaccines and mechanisms of tolerance induction. Ed has served as Director of the Stanford Blood Center since 1979.

Patricia Jones received her PhD from The Johns Hopkins University; while a graduate student, she visited the Herzenberg laboratory to carry out some of the first experiments with the newly invented fluorescence-activated cell sorter. After an initial postdoctoral position at UCSF, Pat did a second postdoc jointly between the Herzenberg and McDevitt laboratories, where she helped to elucidate the structure and genetics of MHC class II proteins, discovered the class II-associated invariant chain and helped produce the first monoclonal antibodies to lymphocyte cell surface proteins (MHC class I and class II proteins and $\operatorname{IgM}$ and $\mathrm{IgD}$ allotypes). Her research has focused on the structure, function and regulation of expression of MHC class II proteins and on mechanisms regulating adaptive and innate immune responses. Since joining the Biology Department faculty, Pat has taught the introductory molecular and cellular immunology course; alumni of her course now hold immunology positions around the country. She has held several university leadership positions and has served as Director of Stanford Immunology since 2011.

Peter Parham and Lawrence Steinman joined the faculty in 1980, in Structural Biology and Neurology, respectively. Peter received his PhD and was a Junior Fellow at Harvard. Working with Jack Strominger at Harvard and Walter Bodmer at Oxford, he helped determine the structure of purified HLA class I proteins and utilized early monoclonal antibodies in studies of HLA biochemistry and genetics. At Stanford, his research has focused on structural, genetic, functional and comparative evolutionary aspects of HLA class I proteins, most recently focusing on the genetics and evolution of interactions between HLA class I and variable NK cell receptors.

Lawrence Steinman received his MD from Harvard, followed by postdoctoral training at the Weizmann 
Institute in Israel and residency in Neurology at Stanford. As a faculty member in Neurology and Neurological Sciences, he has helped develop and use the murine model of multiple sclerosis, experimental autoimmune encephalomyelitis (EAE), for elucidating mechanisms underlying the occurrence of EAE and MS, including the roles of MHC class II proteins, T-cell receptors and specific T-cell subsets. Larry has also developed innovative immunotherapeutic agents for treating these and other autoimmune diseases and has explored the mechanisms underlying their protective effects. He served as Director of Stanford Immunology from 2002 to 2011.

In the early 1980s, two new faculty joined the Division of Immunology and Rheumatology of the Department of Medicine, Garry Fathman and Jane Parnes. Garry obtained his MD from Washington University School of Medicine, and after completing his clinical training at Dartmouth, pursued a postdoc at Stanford working with Hugh McDevitt and Len Herzenberg, followed by a position as a clinical associate at the NIH. His early research focused on characterizing thymocyte and peripheral T-cell subsets, using the early FACS, and the functions of MHC class II proteins. After several years at the Basel Institute of Immunology and on the faculty of the Mayo Clinic, Garry returned to Stanford in 1981. His research has focused on genetic control of immune responses by MHC class II proteins in mice, rats and humans, the development and utilization of T-cell clones to explore the specificity of Tcell responses and T-B interactions, mechanisms of allograft rejection and tolerance induction, processes underlying tolerance breakdown in NOD mice leading to type 1 diabetes, genes and mechanisms inducing T-cell anergy and, most recently, development of immunotherapeutic approaches for treating type 1 diabetes in humans. He served as Chief of Immunology and Rheumatology for 15 years, as Director of the Center for Clinical Immunology at Stanford and as President of both the Clinical Immunology Society and the Federation of Clinical Immunology Societies.

Jane Parnes did her medical training at Harvard and Massachusetts General Hospital, followed by postdoctoral training at MIT and the NIH. After joining the Stanford faculty in 1982, she characterized CD4 and CD8 genes, proteins, regulation of expression and functions in T-cell development and activation. Her group also characterized the functions and interactions of other lymphocyte proteins, including T-cell CD5, its ligand CD72 (which attenuates Bcell activation) and the T-cell signaling attenuator protein CD6. In 2006, Jane left Stanford to become Medical Director at AMGEN.

Eugene Butcher also joined the faculty in 1982, in the Pathology Department. After receiving his MD from Washington University, he did his residency, postdoctoral and fellowship training in pathology at Stanford. Working with Irv Weissman, Eugene made pivotal contributions to the discovery and characterization of lymphocyte homing receptors and the roles of these receptors and of high endothelial venules in lymphocyte subset- and organ-specific migration into lymphoid organs. As a faculty member in Pathology, he has continued his pioneering research on mechanisms by which leukocytes home to specific tissues in normal, inflammatory and disease states in animals and humans. His group has also elucidated the multistep process from leukocyte binding to extravasation, including the critical roles of chemokines and differentially expressed chemokine receptors in determining the cell-type- and tissue specificity of leukocyte homing.

Mark Davis joined the faculty of the Microbiology and Immunology Department in 1983. Having received his $\mathrm{PhD}$ from Caltech, he was a postdoc and staff fellow at the $\mathrm{NIH}$, where he and Steve Hedrick were the first to clone a T-cell receptor gene, a pivotal breakthrough that opened the door for an explosion of discoveries about T-cell receptor genes and proteins. At Stanford, Mark's research has continued to be at the forefront of studies of T-cell receptor molecular genetics, structures and functions. Included have been pioneering studies of the structural basis for TCR recognition of peptide/MHC complexes, immunological synapses, and mechanisms and requirements for T-cell signaling and activation. These discoveries have often been enabled by the laboratory's development of novel techniques, such as MHC tetramers and new methods in fluorescence labeling and microscopy. In recent years, Mark has developed a major focus on human immunology, including the characterization of T-cell repertoires in normal individuals and those responding to infection or vaccination. He was named an investigator of the Howard Hughes Medical Institute in 1991 and elected to the National Academy of Sciences in 1993. In 2004, he was appointed as the first director of the new Institute for Immunity, Transplantation, and Infection of Stanford University School of Medicine.

\section{Stanford Immunology today}

Many additional immunologists have joined the Stanford faculty in the more than 30 years since the events of its first 25 years, described above. Currently $\sim 75$ Stanford faculty members consider themselves immunologists and contribute to immunology activities. Despite the growth in numbers of laboratories and their distribution across many departments and divisions, the immunology community has continued the tradition of interaction and collaboration experienced by the early immunologists, as described above. Thus, there are many research collaborations, shared journal 
clubs, the weekly Stanford Immunology Seminars and the long-standing annual immunology retreat, usually at the Asilomar Conference Center in Pacific Grove. As has been true since the move of the School of Medicine from San Francisco to Stanford in 1959, immunology has benefited from close contacts with other fields of science and engineering on campus. The development of new research techniques that enable novel discoveries to be made has continued to be a feature of immunology and other biomedical sciences at Stanford. This tradition has continued, with the development of a variety of microarray approaches and of the CyTOF flow cytometer (utilizing time-off-flight mass spectrophotometer-based detection of cells stained with heavy metal-coupled antibodies) as a unique tool for phenotyping cells [65]. Translational immunology has also been a long-standing strength at Stanford. Additional emphasis on human immunology has come with the establishment in 2004 of the Institute for Immunity, Transplantation and Infection (Mark Davis, Director) and its Human Immune Monitoring Core (http://iti.stanford.edu/).

In parallel to the growth of immunology research at Stanford has come the expansion and enrichment of immunology training programs. The Cellular and Molecular Immunobiology training grant from NIAID was funded in 1984 (under the leadership of then PI Irv Weissman), initially supporting only postdocs. It was expanded in 1988 to also support graduate students in the newly established interdepartmental $\mathrm{PhD}$ Program in Immunology. The training grant has been continuously funded since its inception. Today, the many immunology training-related activities are organized under the umbrella structure called Stanford Immunology. The PhD Program in Immunology currently has 48 graduate students in two $\mathrm{PhD}$ tracks: Molecular, Cellular and Translational Immunology, and Computational and Systems Immunology. Many alumni of our graduate and postdoctoral programs have continued in immunology and other areas of the biomedical sciences in academia, industry, and the government. They have themselves continued the Stanford Immunology community's tradition of pioneering new discoveries and their application to improving human health.

\section{References}

1. Holman HR. Autoimmune reactions in systemic lupus erythematosus. NY State J Med. 1959;59:3971-3.

2. Nossal GJ, Lederberg J. Antibody production by single cells. Nature. 1958;181:1419-20.

3. Sir Frank Macfarlane Burnet 1899-1985. Nat Immunol. 2007; 8:1009-1009.

4. Herzenberg LA. Studies on the induction of b-galactosidase in a cryptic strain of escherichia coli. Biochem Biophys Acta. 1959;31:525-38.
5. Herzenberg LA, Roosa RA. Nutritional Requirements for growth of a mouse lymphona in cell culture. Exp Cell Res. 1959;21:430 8.

6. Cann HM, Herzenberg LA. In vitro studies of mammalian somatic cell variation. II. Isoimmune cytotoxicity with a cultured mouse lymphoma and selection of resistant variants. J Exp Med. 1963;117:267-84.

7. Herzenberg LA, Gonzales B. Appearance of $\mathrm{H}-2$ agglutinins in outcrossed female mice. Proc Natl Acad Sci. 1962;48:570-3.

8. Herzenberg Leonard A, Herzenberg Leonore A. Association of mouse $\mathrm{H}-2$ antigens with the cell membrane fraction of mouse liver. Proc Natl Acad Sci USA. 1961;47(6):762-7.

9. Nossal GJ, Makela O. Kinetic studies on the incidence of cells appearing to form two antibodies. J Immunol. 1962;88:604-12.

10. Erickson RP, Tachibana DK, Herzenberg LA, Rosenberg LT. A single gene controlling hemolytic compliment and a serum antigen in the mouse. J Immunol. 1964;92:611-5.

11. Brown M, Henry S. Kaplan distinguished scientist award lecture 2007. The remarkable yin and yang of tumour hypoxia. Int $\mathbf{J}$ Radiat Biol. 2010;86:907-17.

12. Gladstein E. As good as it gets-training with Henry Kaplan and Saul Rosenberg during the Stanford studies on Hodgkin's disease and lymphoma. Cancer Biother Radiopharm. 2001;16:269-73.

13. Wunderlich J, Herzenberg LA. Genetics of a gamma globulin isoantigen (Allotype) in the mouse. Proc Natl Acad Sci. 1963;49:592-8.

14. Herzenberg LA, Minna JD, Herzenberg LA. A chromosome region for immunoglobulin heavy chains in the mouse: allelic electrophoretic mobility differences and allotype suppression. Cold Spring Harb Symp Quant Biol. 1967;XXXII:181-6.

15. Herzenberg LA, Herzenberg LA. Genetics FACS, immunology, and redox: a tale of two lives intertwined. Annu Rev Immunol. 2004;22:1-31.

16. Herzenberg LA, Herzenberg LA. Our NIH years: a confluence of beginnings. J Biol Chem. 2013;288:687-702.

17. Herzenberg LA, Herzenberg LA, Roederer MA. Conversation with Leonard and Leonore Herzenberg. Annu Rev Physiol. 2014;76:1-20.

18. Herzenberg LA, Rindfleisch T, Herzenberg LA. Joshua Lederberg: the Stanford years (1958-1978). Annu Rev Genet. 2008;42:19-25.

19. Herzenberg LA, Sweet RG. Fluorescence-activated cell sorting. Sci Am. 1976;234:108-17.

20. Hulett HR, Bonner WA, Sweet RG, Herzenberg LA. Development and application of a rapid cell sorter. Clin Chem. 1973;19:813-6.

21. Bodmer J, Bodmer W. Rose Payne, 1909-1999. Tissue Antigens. 1999;54:102-3.

22. Grumet FC. Memorial resolution: Rose O. Payne, Ph.D. Stanford University. 1999. http://historicalsociety.stanford.edu/pdfmem/ Payne_Rose.pdf.

23. Payne R. Leukocyte agglutinins in human sera. Arch Intern Med. 1957;99:587.

24. Payne R. The association of febrile transfusion reactions with leukoagglutinins. Vox Sang. 1957;2:233.

25. Payne R, Rolfs M. Fetomaternal leukocyte incompatibility. J Clin Invest. 1958;37:1756-63.

26. Bodmer W, Bodmer J. History of HLA: recollections of a golden age. In: Terasaki PI, editor. History of HLA: ten recollections. UCLA Tissue Typing Laboratory: Los Angeles; 1990. p. 93-120.

27. Bodmer $\mathrm{W}$, personal communication.

28. Payne R, Tripp M, Weigle J, Bodmer W, Bodmer J. A new leukocyte isoantigen system in man. Cold Spring Harbor Symp Quant Biol. 1964;29:285-95.

29. Nagourney E. Rose Payne, 89 , scientist who aided transplants. New York Times, 27 April 1999. http://www.nytimes.com/1999/ 04/27/us/rose-payne-89-scientist-who-aided-transplants.html. 
30. Bodmer WF, Tripp M, Bodmer J. Application of fluoro-chromatic cytotoxicity assay to human leukocyte typing. In: Curtoni ES, Mattiuz PL, Tosi RM, editors. Histocompatibility testing 1967. Copenhagen: Munksgaard; 1967. p. 341-50.

31. McDevitt HO. Discovering the role of the major histocompatibility complex in the immune response. Annu Rev Immunol. 2000;18: $1-17$.

32. McDevitt HO, Sela M. Genetic control of the antibody response. I. Demonstration of determinant-specific differences in response to synthetic polypeptide antigens in two strains of inbred mice. J Exp Med. 1965;122:517-31.

33. McDevitt HO, Sela M. Genetic control of the antibody response. II. Further analysis of the specificity of determinant-specific control, and genetic analysis of the response to $(\mathrm{H}, \mathrm{G})-\mathrm{A}-\mathrm{L}$ in CBA and C57 mice. J Exp Med. 1967;126:969-78.

34. McDevitt HO, Tyan ML. Genetic control of the antibody response in inbred mice: transfer of response by spleen cells and linkage to the major histocompatibility locus. J Exp Med. 1968;128:1-11.

35. McDevitt HO, Deak BD, Shreffler DC, Klein J, Stimpfling JL. Genetic control of the immune response. Mapping of the Ir-1 locus. J Exp Med. 1972;135:1259-78.

36. Bach FH, Widmer MB, Bach ML, Klein J. Serologically defined and lymphocyte-defined components of the major histocompatibility complex in the mouse. J Exp Med. 1972;136:1430-44.

37. Hammerling GJ, Deak BD, Mauve G, Hammerling U, McDevitt HO. B-lymphocyte alloantigens controlled by the I-region of the major histocompatibility complex in mice. Immunogenetics. 1974;1:68-81.

38. Press JL, McDevitt HO. Allotype-specific analysis of anti-(Tyr, Glu)-Ala-Lys antibodies produced by Ir-1 high and low responder chimeric mice. J Exp Med. 1977;146:1815-20.

39. Grumet FC, Coukell A, Bodmer JG, Bodmer WF, McDevitt HO. Histocompatibility (HLA) antigens associated with systemic lupus erythematosus. A possible genetic predisposition to disease. N Engl J Med. 1971;285:193-6.

40. McDevitt HO, Bodmer WF. Histocompatibility antigens, immune responsiveness, and susceptibility to disease. Am J Med. 1972;52:1-8.

41. Acha-Orbea H, McDevitt HO. The first external domain of the non-obese diabetic mouse class II I-A $\beta^{\mathrm{g} 7}$ is unique. Proc Natl Acad Sci USA. 1987;84:2435-9.

42. Todd JA, Bell JI, McDevitt HO. HLA-DQb gene contributes to susceptibility and resistance to insulin-dependent diabetes mellitus. Nature. 1987;329:599-604.

43. Weissman IL. The road ended up at stem cells. Immunol Rev. 2002;185:159-84.

44. Eichwald EJ, Lustgraaf EC, Weissman IL. Sex-linked rejection of normal and neoplastic tissue. I. Distribution and specificity. J Natl Cancer Inst. 1958;20:563-75.

45. Weissman IL. personal communication.

46. Weissman IL. Lymphocytes, Jim Gowans, and in vivo veritas. Nat Immunol. 2010;11:1073-5.

47. Weissman IL. Thymus cell migration. J Exp Med. 1967;126: 291-304.

48. Muller-Sieburg C, Whitlock CA, Weissman IL. Isolation of two early B lymphocyte progenitors from mouse marrow: a committed pre-pre B cell and a clonogenic Thy-1 lo hematopoietic stem cell. Cell. 1986;44:653-62.

49. Spangrude GJ, Heimfeld S, Weissman IL. Purification and characterization of mouse hematopoietic stem cells. Science. 1988;241:58-62.

50. Weissman IL, Shizuru JA. The origins of the identification and isolation of hematopoietic stem cells, and their capability to induce donor-specific transplantation tolerance and treat autoimmune diseases. Blood. 2008;112:3543-53.
51. Tseng D, Volkmer JP, Willingham SB, Contreras-Trujillo H, Fathman JW, Fernhoff NB, Seita J, Inlay MA, Weiskopf K, Miyanishi M, Weissman IL. Anti-CD47 antibody-mediated phagocytosis of cancer by macrophages primes an effective antitumor T-cell response. Proc Natl Acad Sci USA. 2013;110:11103-8.

52. Fathman JW, Bhattacharya D, Inlay MA, Seita J, Karsunky H, Weissman IL. Identification of the earliest natural killer cellcommitted progenitor in murine bone marrow. Blood. 2011; 118:5439-47.

53. Chan CK, Lindau P, Jiang W, Chen JY, Zhang LF, Chen CC, Seita J, Sahoo D, Kim JB, Lee A, Park S, Nag D, Gong Y, Kulkarni S, Luppen CA, Theologis AA, Wan DC, DeBoer A, Seo EY, Vincent-Tompkins JD, Loh K, Walmsley GG, Kraft DL, Wu JC, Longaker MT, Weissman IL. Clonal precursor of bone, cartilage, and hematopoietic niche stromal cells. Science. 2013; 341:384-7.

54. Strober S. Path to clinical transplantation tolerance and prevention of graft versus host disease. Immunol Res 2014; Mar 27. Epub ahead of printPMID:24671802.

55. Slavin S, Fuks Z, Kaplan HS, Strober S. Transplantation of allogeneic bone marrow without graft-versus-host disease using total lymphoid irradiation. J Exp Med. 1978;147:963-72.

56. Slavin S, Reitz B, Bieber CP, Kaplan HS, Strober S. Transplantation tolerance in adult rats using total lymphoid irradiation: permanent survival of skin, heart, and marrow allografts. J Exp Med. 1978;147:700-7.

57. Scandling JD, Busque S, Dejbakhsh-Jones S, Benike C, Millan MT, Shizuru JA, Hoppe RT, Lowsky R, Engleman EG, Strober S. Tolerance and chimerism after renal and hematopoietic-cell transplantation. N Engl J Med. 2008;358:362-8.

58. Scandling JD, Busque S, Dejbakhsh-Jones S, Benike C, Sarwal M, Millan MT, Shizuru JA, Lowsky R, Engleman EG, Strober S. Tolerance and withdrawal of immunosuppressive drugs in patients given kidney and hematopoietic cell transplants. Am J Transplant. 2012;12:1133-45.

59. Levy R. A brief personal history of cancer immunotherapy at Stanford. If these walls could talk. Immunol Res. 2014. doi:10. 1007/s12026-014-8506-3.

60. Levy R, Warnke R, Dorfman RF, Haimovich J. The monoclonality of human B-cell lymphomas. J Exp Med. 1977;145: 1014-28.

61. Maloney DG, Liles TM, Czerwinski DK, Waldichuk C, Rosenberg J, Grillo-Lopez A, Levy R. Phase I clinical trial using escalating single-dose infusion of chimeric anti-CD20 monoclonal antibody (IDEC- C2B8) in patients with recurrent B-cell lymphoma. Blood. 1994;84:2457-66.

62. Kohrt HE, Thielens A, Marabelle A, Sagiv-Barfi I, Sola C, Chanuc F, et al. Anti-KIR antibody enhancement of anti-lymphoma activity of natural killer cells as monotherapy and in combination with anti-CD20 antibodies. Blood. 2014;123: 678-86.

63. Marabelle A, Kohrt H, Sagiv-Barfi I, Ajami B, Axtell RC, Zhou G, Levy R. Depleting tumor-specific tregs at a single site eradicates disseminated tumors. J Clin Invest. 2013;123:2447-63.

64. Brody JD, Ai WZ, Czerwinski DK, Torchia JA, Levy M, Advani RH, Levy R. In situ vaccination with a TLR9 agonist induces systemic lymphoma regression: a phase I/II study. J Clin Oncol. 2010;28:4324-32.

65. Bjornson ZB, Nolan GP, Fanti WJ. Single-cell mass cytometry for analysis of immune system functional states. Curr Opin Immunol. 2013;25:484-94. 